\title{
FACTORS GOVERNING THE DISTRIBUTION OF SWAINSON'S WARBLER ALONG A HYDROLOGICAL GRADIENT IN GREAT DISMAL SWAMP
}

\author{
GARY R. GRAVES ${ }^{1}$ \\ Department of Vertebrate Zoology, National Museum of Natural \\ History, Smithsonian Institution, Washington, D.C. 20560, USA
}

\begin{abstract}
Due to extensive clearing of bottomland forest in the southeastern United States, Swainson's Warbler (Limnothlypis swainsonii) is restricted in many drainages to seasonally inundated buffer zones bordering rivers and swamps. This migratory species is especially vulnerable to flooding because of its ground foraging ecology, but little is known about patterns of habitat occupancy at wetland ecotones. I investigated the physiognomic and floristic correlates of habitat use along a subtle hydrological gradient in the Great Dismal Swamp, southeastern Virginia. Hydrology is the driving force influencing vegetation and the distribution of Swainson's Warbler in that habitat. Foraging and singing stations of territorial males were significantly drier and more floristically diverse than unoccupied habitat. There was scant evidence that the distribution and abundance of particular plant species, including giant cane (Arundinaria gigantea), influenced habitat selection. Instead, Swainson's Warbler seems to evaluate potential territories on the basis of multiscale physiognomic, hydrological, and edaphic characteristics. Territories were characterized by extensive understory thickets (median $=36,220$ small woody stems and cane culms per hectare; range, 14,000-81,400/ha), frequent greenbriar tangles, deep shade at ground level, and an abundance of leaf litter overlying moist organic soils. Those sites occurred most frequently in relatively well-drained tracts of broad-leaf forest that had suffered extensive canopy damage and windthrow. Data suggest a preference for early successional forest in the current landscape or disturbance gaps in primeval forest. Because territories in otherwise optimal habitat are abandoned when flooding extends into the breeding season, it is recommended that the water table be maintained at subsurface levels from late March through September in natural areas managed primarily for this species. Direct and indirect environmental factors that influence the breeding biology of the warbler are summarized in an envirogram. Received 16 February 2000, accepted 20 January 2001.
\end{abstract}

PATTERNS OF AVIAN DISTRIBUTION AND ABUNDANCE depend largely on how individual birds perceive and use habitat at local, regional, and continental scales (e.g. Cody 1985, Wiens 1989, Orians and Wittenberger 1991). The explosive growth of research on avian habitat selection since Grinnell (1917) and Lack (1933) has generated considerable insight on the intertwined influences of habitat physiognomy and floristics as correlates of microhabitat preferences (e.g. MacArthur 1958, Franzreb 1978, Holmes and Robinson 1981, Robinson and Holmes 1984, Rotenberry 1985, Parrish 1995), the innate behavior of habitat choice (e.g. Partridge 1976, Greenberg 1984, Morton 1990, Morton et al. 1993), and intraspecific geographic variation in habitat selection (e.g. Dow 1968, Collins 1983, James et al. 1984). Mounting evidence

\footnotetext{
${ }^{1}$ E-mail: graves.gary@nmnh.si.edu
}

suggests that passerines choose among gross habitat types on the basis of physiognomy but may be sensitive to floristic cues in selecting microhabitats (Rotenberry 1985). In exceptional cases, the ecology of local populations may be inextricably linked to a single tree species (e.g. Benkman 1999). More commonly the physiognomic and floristic factors governing the distribution of wide-ranging avian species can be characterized only in the most general terms. Analysis of potential regulating influences, always difficult without experimental manipulation, is facilitated by a descriptive species-centered analysis of habitat selection along environmental or geographic gradients (Grinnell 1917, James et al. 1984), an approach that I embraced in this paper.

Swainson's Warbler (Limnothlypis swainsonii) is an uncommon and locally distributed migratory passerine that breeds in the southeastern 
United States and winters in the Caribbean Basin (Meanley 1971, Brown and Dickson 1994, Price et al. 1995, Graves 1996). Recent surveys indicate that most $(>90 \%)$ breeding populations occur in deciduous floodplain forest in the lower Mississippi Valley and on the coastal plain from eastern Texas to southeastern Virginia (G. Graves unpubl. data). Within the past 30 years, several populations have disappeared along the northern periphery of the warbler's historic breeding range in Delaware, Maryland, Missouri, and Illinois (Robbins and Easterla 1992, Brown and Dickson 1994). Some authorities suspect that it may be susceptible to range-wide population declines because of habitat destruction and a small wintering range in the Caribbean Basin (Terborgh 1989, Rappole 1995). The conversion of bottomland forests for agriculture, reservoirs, pine plantations, and suburban housing developments, has substantially reduced the area of suitable habitat above the mean vernal high-water level in large parts of its breeding range. Swainson's Warbler is now restricted to seasonally inundated buffer zones along rivers and swamps in several drainages. Ultimately, long term survival of the species may depend on its ability to reproduce successfully in annually flooded wetlands that are economically risky to develop. Consequently, the discovery and management of viable breeding and wintering populations of this flagship species are urgent conservation priorities (Hunter et al. 1993, Smith et al. 1993, Thompson et al. 1993).

The breeding ecology of Swainson's Warbler has been the subject of intense ornithological interest since the nineteenth century (Brewster 1885a,b; Wayne 1886, Meanley 1945, 1966, 1971; Graves et al. 1996). A clear understanding of its habitat requirements has been slow to develop, however, because of the species' rarity, secretive behavior, large territory size, and the inhospitable, often impenetrable, nature of its breeding habitat (Graves 1998). The frequent association of Swainson's Warbler with giant cane (Arundinaria gigantea) was noted as early as the 1880s (Brewster 1885a, Beckham 1887). Brewster (1885a:72) observed, "four things seem indispensable to his existence, viz., water, tangled thickets, patches of cane, and a rank growth of semi-aquatic plants." Despite published exceptions (Widmann 1895), by the 1920 s it was widely believed that breeding pop- ulations were more or less restricted to canebrakes in deep swamps and bottomland forest (e.g. Howell 1924, 1932; Pearson et al. 1919).

The surprising discovery of several populations of Swainson's Warbler in thickets of rhododendron and mountain laurel in the Appalachian Mountains (Brooks and Legg 1942) considerably expanded the range of habitats in which the species was known to breed. Probable breeding populations have now been documented in a perplexing variety of habitats that lack canebrakes: for example, (1) fragments of old growth bottomland forest, (2) early seral stages (10-30 years) of deciduous bottomland forest, (3) young pine plantations with a significant deciduous component, (4) live oak thickets and old growth live oak forests in coastal Texas, (5) second growth bottomland forest with scrub palmetto undergrowth, (6) Rhododendron and Kalmia thickets in the Appalachian Mountains, and (7) hardwood cove forests in the Appalachians (Brooks and Legg 1942, Sims and DeGarmo 1948, Meanley 1966, 1971, Brown and Dickson 1994, W. Barrow pers. comm.; G. Graves unpubl. data). Although there can be little doubt that large canebrakes in bottomland forests provide prime breeding habitat for Swainson's Warbler, it is clear from the aforementioned examples that giant cane, per se, is not required.

I investigated the environmental factors correlated with the distribution of Swainson's Warbler along a subtle hydrological gradient in unfragmented forest in Great Dismal Swamp, southeastern Virginia. I addressed four principal questions: (1) Is the habitat physiognomy of male territories, particularly of foraging microhabitats, distinguishable from that of contiguous but unoccupied habitat? (2) Is microhabitat selection linked to the density and patchiness of giant cane? (3) Are there floristic differences between occupied and unoccupied sites? (4) Is habitat selection of Swainson's Warbler in Great Dismal Swamp related to spatial distribution of pooled or standing water? I then graphically summarized the environmental factors that influence the distribution and abundance of Swainson's Warbler in an "envirogram" (Andrewartha and Birch 1984, Van Horne and Wiens 1991, James et al. 1997). I conclude the paper with a discussion of hydrological management in Great Dismal Swamp. 


\section{METHODS}

Site description.-Great Dismal Swamp, an $850 \mathrm{~km}^{2}$ palustrine wetland in southeastern Virginia and northeastern North Carolina, is one of the largest remaining tracts of unfragmented forest on the Atlantic Coastal Plain of North America. Present boundaries of forest in Great Dismal Swamp in Virginia are largely coincident with those of the Great Dismal Swamp National Wildlife Refuge (GDSNWR), which probably represents the heart of the original swamp. The study was conducted in the northwestern corner of GDSNWR (Fig. 1), southeast of the city of Suffolk, and east of the largely deforested Suffolk Scarp, a Pleistocene shoreline that rises abruptly to form the western border of the swamp at 18-21 m above sea level (Oaks and Coch 1973, Whitehead 1972, Whitehead and Oaks 1979, Lichtler and Walker 1979). The face of the scarp slopes abruptly eastward at rates approaching $25 \mathrm{~m} / \mathrm{km}$, to elevations of 7-9 $\mathrm{m}$ above sea level. The swamp slopes eastward from the base of the scarp at $\sim 0.2 \mathrm{~m} / \mathrm{km}$. Topographic relief within the study area is $<1 \mathrm{~m}$. The swamp is underlain by the impermeable Yorktown Formation of early Pliocene age. Ground water discharges from the Tabb Aquifer at the western margin of the swamp and flows eastward. For reference, vegetation sampling transect " $\mathrm{A}$ " of Carter et al. (1988) and Carter et al. (1994) intersects the Suffolk Scarp on the western boundary of the study area.

The hydrology of Great Dismal Swamp has been greatly altered by the construction of the Feeder Ditch (constructed in 1812), connecting Dismal Swamp Canal to Lake Drummond, and dozens of other ditches and their accompanying spoil banks that crisscross the swamp. The flow of water in the study area (Fig. 1) is governed by spoil banks bordering Jericho Ditch (constructed around 1810) and Lynn Ditch (constructed prior to 1930) and several control structures and fixed level weirs in ditches. Water levels are typically high during winter and early spring and decrease during the growing season (April-May) as transpiration increases.

Mature timber has been cut several times since the shareholders of Dismal Swamp Land Company, including George Washington, received claim to the western half of Great Dismal Swamp in 1764. When logging began, the study area was dominated by swamp black gum (Nyssa sylvatica var. biflora), water tupelo (Nyssa aquatica), bald cypress (Taxodium distichum), and Atlantic white cedar (Chamaecyparis thyoides) (Kearny 1901, Levy 1991). Older culls and snags left by previous episodes of logging are sparsely distributed ( $<1 /$ ha) throughout the northwestern corner of the GDSNWR. Swamp forest in the study area, now 40-80 years old, is unfragmented except for narrow breaks in the canopy along the ditches and scattered windthrow gaps. The impenetrable character of the swamp's understory was pointedly

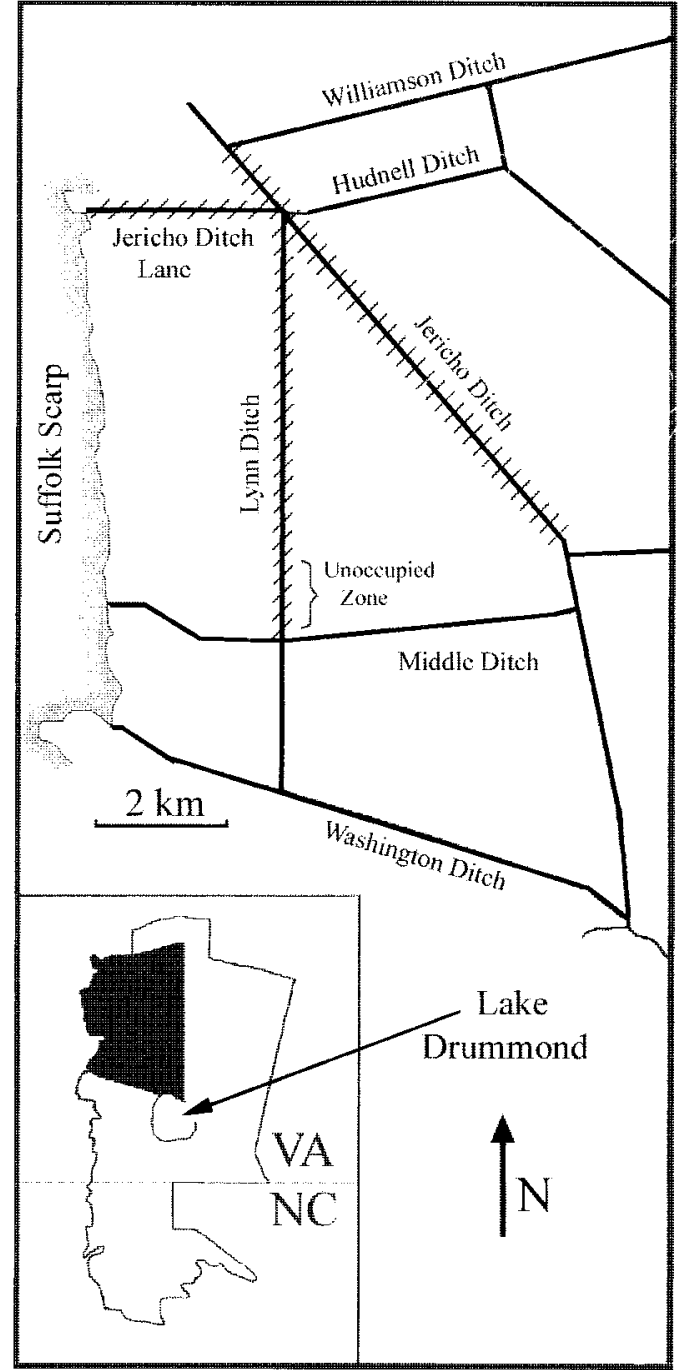

FIG. 1. Study area and census transects (hatched area) east of Suffolk Scarp in Great Dismal Swamp National Wildlife Refuge, Virginia and North Carolina. Location of study site (black area) is depicted in the inset map.

observed by William Byrd (1967:65) during a survey of the swamp in 1728: "The reeds [giant cane], which grew about 12 feet high, were so thick, and so interlaced with bamboo-briars [Smilax laurifolia], that our pioneers were forced to open a passage." Today as in the past, passage through much of the study area can be accomplished only by cutting a pathway.

The forest canopy is currently dominated by red maple (Acer rubrum) and swamp black gum, with lesser amounts of red bay (Persea borbonia), sweetbay magnolia (Magnolia virginiana), American holly (Ilex opaca), sweetgum (Liquidambar styraciflua), tulip pop- 
lar (Liriodendron tulipifera), water oak (Quercus nigra), laurel oak ( $Q$. laurifolia), bald cypress, Atlantic white cedar, and loblolly pine (Pinus taeda) (Levy and Walker 1979, Carter et al. 1994). A rich shrub flora includes coastal pepperbush (Clethra alnifolia), sweet spires (Itea virginica), swamp sweetbells (Leucothoe racemosa), coastal sweetbells (L. axillaris), fetterbush (Lyonia lucida), maleberry (Ly. ligustrina), gallberry (Ilex glabra, I. coriacea), highbush blueberry (Vaccinium corymbosum), wild raisin (Viburnum nudum), huckleberry (Gaylussacia frondosa), sweetleaf (Symplocos tinctoria), and pink azalea (Rhododendron nudiflorum). Giant cane (Arundinaria gigantea) is patchily distributed, but forms dense brakes where it occurs. Common woody vines in the study area include poison ivy (Rhus radicans), Virginia creeper (Parthenocissus quinquefolia), cross vine (Anisostichus capreolata), yellow jessamine (Gelsemium sempervirens), climbing hydrangea (Decumaria barbara), and muscadine grape (Vitus rotundifolia) (taxonomy follows Musselman et al. 1977). Nearly impenetrable stands of greenbriar (S. laurifolia, S. rotundifolia) are abundantly distributed throughout the study area, particularly in the vicinity of windthrow gaps.

Climate of the study area is temperate with long warm summers and mild winters. The growing season varies from $<174$ days $(10 \%$ of years) to $>209$ days (10\% of years), averaging 192 days (Reber et al. 1981). Annual rainfall averages $1,280 \mathrm{~mm}$ with most precipitation falling in July and August (U.S. Weather Bureau 1965).

Soil characteristics of the study area are of significant interest in view of the terrestrial foraging ecology of Swainson's Warbler (Graves 1998). The Suffolk Scarp is crowned by well-drained sandy loams with low organic content. Water-retaining capacity and organic content of soils increase rapidly with decreasing elevation along the east-facing flank of the scarp. Soils along the transects are poorly drained, moderately to extremely acidic, and classified in the Torhunta-Deloss and Pungo-Belhaven associations (Reber et al. 1981). Both soil associations are subject to regular flooding in winter and spring. Scattered to extensive pools of water may persist during the nesting season (April-July), particularly in the southwestern corner of the study site.

Spatial distribution of warblers.-The Great Dismal Swamp supports the northernmost viable population of Swainson's Warbler on the Atlantic Coastal Plain. Males arrive and establish territories during the third week of April (Meanley 1966, 1971) when the water table is at the highest level during the breeding cycle. The earliest record of nest building is 23 April (Meanley 1971).

Motorized access to the study area was limited to roads built atop spoil banks (0.5-1.0 $\mathrm{m}$ above ground level) that parallel ditches. I mapped territorial boundaries each year (17 May-3 June, 1989-1994) with the aid of "playback-and-follow" trials along 18 $\mathrm{km}$ of transects along spoilbanks. A full discussion of census techniques will be published elsewhere. Briefly, loop cassette tapes (60 s) were prepared from song recordings of two or more males interspersed with $5 \mathrm{~s}$ of call notes. Recordings were broadcast from a dual-speaker portable tape player. Power output was variable due to battery strength and temperature, but the audio output was adjusted before every census run so that songs were faintly audible to me at a distance of $100 \mathrm{~m}$ (unobstructed by vegetation). The estimated effective census width was $\sim 250 \mathrm{~m}$ based on the response of territorial males to the playback of songs. Approximately half of the males was color-banded each year.

Vegetation sampling in Swainson's Warbler territories.-Swainson's Warbler territories in Great Dismal Swamp were large (3-18 ha) and physiognomically complex. The sheer size of territories presented a vegetation sampling problem. First, when sampling sites were randomly distributed within a territory, many plots were located in patches of habitat that were seldom used by warblers (e.g. areas with sparse undergrowth) or avoided entirely (e.g. flooded swales). Furthermore, the labor needed to quantify the vegetation on just $5 \%$ of a typical territory (10 ha) was estimated at 45 man hours ( $\sim 4 \mathrm{~h} /$ sampling plot). Given the limitations in amount of help, I centered a single circular sampling plot $(0.045 \mathrm{ha}$; diameter $=24 \mathrm{~m}$ ) at the first terrestrial site in each territory at which the undisturbed color-banded male was observed to both sing and forage. Sampling at dual purpose singing-foraging sites ensured that physiognomic and floristic data actually corresponded to microhabitats used by Swainson's Warblers. Although this paper focuses on habitat selection of males, a substantial body of data indicates that males and females use similar foraging microhabitats (G. Graves 1998 unpubl. data). Foraging observations and the consequent placement of sampling plots were made $40-120 \mathrm{~m}$ from roadsides to minimize "ditch" effects in vegetation sampling. In hindsight, that cautionary procedure was deemed unnecessary because understory thickets bordering ditches did not differ physiognomically or floristically from those associated with frequent canopy disturbances in the forest interior.

All trees (diameter at breast height $[\mathrm{DBH}]>5 \mathrm{~cm}$ ) occurring in sampling plots (0.045 ha) were measured (diameter to nearest centimeter) and identified to species. Diameters were later converted to size classes for comparison, whereas basal area was computed from raw field measurements. Woody vines supported by trees were also counted (1.4 m above ground) and identified.

Small woody stems (DBH $<5 \mathrm{~cm}$; i.e. shrubs, cane, vines, and tree saplings) were counted and identified to species in four subplots $\left(12.6 \mathrm{~m}^{2}\right.$, circle diameter $=4 \mathrm{~m}$ ) positioned at the cardinal compass coordinates on the perimeter of the larger primary plot. The 
typical method of estimating the density of small stems by counting the number intercepted by an observer's outstretched arms (e.g. James and Shugart 1970) was unfeasible, if not impossible, to perform because of the prevalence of thorny greenbriar and the immense number of stems in the forest understory. I obtained exact counts by clipping all small stems within each circular subplot at a height of 0.5 $\mathrm{m}$ above ground. Patchiness of cane was estimated by the coefficient of variation $(\mathrm{CV})$ of culm counts among the four shrub subplots. Habitat data were collected on warbler territories, 23 June to 5 July 1993 $(n=15)$ and 22 June to 4 July $1994(n=15)$.

Characterization of unoccupied habitat.-Patterns of habitat selection in passerine birds are often correlated with intraspecific population density (e.g. Kluijver 1951, Fretwell and Lucas 1970, Wiens and Rotenberry 1981, Van Horne 1983, Wiens 1989). For instance, low-quality habitat is often occupied only during high-density years. Characterization of habitat selection thus has limited relevance in the absence of population density estimates. Swainson's Warbler territories in Great Dismal Swamp are large relative to those of other migratory wood warblers (Nolan 1978, Morse 1989). Annual censuses revealed that a majority of territories appeared to abut one another, whereas a minority were separated from their nearest neighbors by significant gaps $(>750 \mathrm{~m})$. Although occupancy patterns fluctuated from year to year, the census population was relatively stable (G. Graves unpubl. data). Cumulative overlays of territory maps prepared after the fourth annual census (1992) showed that virtually all habitat traversed by census transects had been occupied during one or more breeding seasons. However, an unoccupied area ( $\sim 1.2 \mathrm{~km}$ in length) was identified along both sides of Lynn Ditch immediately north of Middle Ditch (Fig. 1). My puzzlement about the underlying cause of the chronic distributional hiatus-the only such gap detected along $18 \mathrm{~km}$ of census transects in unfragmented forest-provided the motivation for this paper.

The unoccupied zone was sampled in a stratified randomized design. The $1.2 \mathrm{~km}$ segment was gridded into 12 blocks (200 m long $\times 100 \mathrm{~m}$ deep), six on each side of the ditch. Four sampling plots, identical to those used in warbler territories, were randomly placed in each block such that plots did not overlap or occur within $10 \mathrm{~m}$ of the ditch or adjacent road. A total of 48 plots were sampled in the unoccupied zone, 2 June to 25 July 1992. Data from four plots were omitted from the analyses after a territorial boundary narrowly overlapped the southeastern corner of the unoccupied zone in 1994.

Pooled water-Flooded territories are abandoned presumably because terrestrial leaf litter is a critical foraging resource (G. Graves unpubl. data). Accordingly, the presence of pooled water was recorded at
20 standardized locations within each sampling plot (five points within each of the four shrub subplots).

Statistics and hypothesis testing.-The original suite of 60 habitat variables was reduced to 24 by combining some variables and eliminating others whose frequency of occurrence was too limited to be useful in analyses or that were highly correlated with other variables (Table 1). Ranges and medians of the retained variables were presented for comparison with previously conducted studies (Eddleman et al. 1980, Thomas et al. 1996). I tested variables for goodness of fit to a normal distribution with Lilliefors test. Ten of 24 variables exhibited significant deviation from normality, even after being subjected to variance-stabilizing transformations (Table 1). Consequently, nonparametric one-way analysis of variance (Kruskal-Wallis ANOVA) was used to examine intergroup differences between occupied and unoccupied habitat, and between warbler territories sampled in 1993 and 1994. Significance values for each suite of hypothesis tests were Bonferroni adjusted for the number of simultaneous tests $(P=0.05 / n)$.

The relationship between pooled water and habitat variables was explored with bivariate scatterplots and Spearman rank correlation coefficients. The cumulative size-class distribution of trees (rows $\times$ columns) in occupied and unoccupied habitat was analyzed with a chi-square test of homogeneity.

I used logistic regression (Hosmer and Lemeshow 1989) of transformed data as a supplementary method of identifying the physiognomic and floristic variables most closely associated with microhabitat selection of Swainson's Warbler. The dependent variable was binary (WARBLER: 0,1), designating unoccupied or occupied habitat, respectively. Those independent variables exhibiting significant $P$-values $(<0.05, n=15)$ in univariate logistic regression analyses were entered into a multiple logistic regression analysis employing a stepwise backward elimination process $(P=0.10)$. Backward elimination removed variables one by one that did not significantly enhance the model's ability to correctly classify site occupancy. In order to identify less complex models that performed reasonably well, I conducted additional simple multiple logistic regression analyses on all possible subsets of variables drawn from the reduced list produced by the stepwise procedure. All analyses were performed with SYSTAT Version 8 (SPSS, 1998).

\section{RESUlts}

Habitat physiognomy.-Between-year differences in habitat variables recorded in Swainson's Warbler territories in 1993 and 1994 were not statistically significant (Kruskal-Wallis ANOVA, $P>0.05$ for all variables). Conse- 
TABLE 1. Medians (ranges) of physiognomic and floristic variables measured on 0.045 ha plots in 30 territories of Swainson's Warblers and in 44 unoccupied areas in the Great Dismal Swamp.

\begin{tabular}{|c|c|c|c|c|}
\hline Code & Variable & Territories & Unoccupied habitat & $\chi^{2}(\mathrm{df}=1)^{\S}$ \\
\hline WAT $^{a}$ & Percent coverage of water & $0.0(0-0)$ & $35.0(0-100)$ & $26.78^{* * *}$ \\
\hline $\mathrm{BAS}^{\mathrm{b}}$ & Total basal area $\left(\mathrm{m}^{2}\right)$ of trees $(\mathrm{DBH}>5 \mathrm{~cm}) / \mathrm{ha}$ & $37.3(26.7-63.5)$ & $45.0(33.1-78.9)$ & $15.28^{* *}$ \\
\hline $\mathrm{ACER}^{\mathrm{b}}$ & Basal area $\left(\mathrm{m}^{2}\right)$ Acer rubrum $(\mathrm{DBH}>5 \mathrm{~cm}) / \mathrm{ha}$ & $23.8(14.6-46.5)$ & $22.6(7.1-33.8)$ & 0.08 \\
\hline NYSSc & Basal area $\left(\mathrm{m}^{2}\right)$ Nyssa sylvatica $(\mathrm{DBH}>5 \mathrm{~cm}) / \mathrm{ha}$ & $5.7(0-29.5)$ & $16.3(6.7-50.0)$ & $34.73^{* * *}$ \\
\hline BOTH $^{c}$ & Basal area $\left(\mathrm{m}^{2}\right)$ all other tree species $(\mathrm{DBH}>5 \mathrm{~cm}) / \mathrm{ha}$ & $4.6(0.4-21.7)$ & $1.3(0-23.4)$ & 7.54 \\
\hline $\mathrm{ONE}^{\mathrm{c}}$ & Trees $(\mathrm{DBH}=5-14.9 \mathrm{~cm}) / \mathrm{ha}$ & $166.7(0-556)$ & $77.7(0-267)$ & $18.62^{* * *}$ \\
\hline $\mathrm{TWO}^{\mathrm{b}}$ & Trees $(\mathrm{DBH}=15-24.9 \mathrm{~cm}) / \mathrm{ha}$ & $244.4(44-556)$ & $300.0(111-711)$ & 3.10 \\
\hline THRE $^{\mathrm{b}}$ & Trees $(\mathrm{DBH}=25-39.9 \mathrm{~cm}) / \mathrm{ha}$ & $144.4(44-467)$ & $322.2(156-600)$ & $60.58^{* * *}$ \\
\hline FOUR $^{\mathrm{b}}$ & Trees $(\mathrm{DBH}=40-59.9 \mathrm{~cm}) / \mathrm{ha}$ & $111.1(22-244)$ & $111.1(44-289)$ & 0.12 \\
\hline FIVEc $^{c}$ & Trees $(\mathrm{DBH}=60-79.9 \mathrm{~cm}) / \mathrm{ha}$ & $44.4(0-133)$ & $44.4(0-133)$ & 0.04 \\
\hline SIX $^{c}$ & Trees $(\mathrm{DBH}>80 \mathrm{~cm}) / \mathrm{ha}$ & $0.0(0-89)$ & $0.0(0-67)$ & 0.82 \\
\hline TREE $^{\mathrm{b}}$ & Trees $(\mathrm{DBH}>5 \mathrm{~cm}) / \mathrm{ha}$ & $777.8(267-1,333)$ & $900.0(578-1,444)$ & 5.46 \\
\hline $\mathrm{TSPE}^{\mathrm{b}}$ & Tree species $(\mathrm{DBH}>5 \mathrm{~cm}) / 0.045$ ha & $5.0(3-7)$ & $4.0(2-6)$ & $11.19^{*}$ \\
\hline VINE $^{\mathrm{d}}$ & Vines (including Smilax spp.) supported by trees/ha & $555.6(22-2,889)$ & $666.7(111-2,755)$ & 0.63 \\
\hline $\mathrm{VSPE}^{\mathrm{b}}$ & Vine species $/ 0.045$ ha & $3.0(1-5)$ & $2.0(1-5)$ & 0.25 \\
\hline $\mathrm{CANE}^{\mathrm{e}}$ & Cane culms / ha & $4,400(0-50,400)$ & $23,300(0-8,000)$ & $22.60^{* * *}$ \\
\hline $\mathrm{CVCA}^{\mathrm{c}}$ & $\begin{array}{l}\text { Cane patchiness: coefficient of variation } \\
\text { of cane culms among four shrub plots }\end{array}$ & $0.55(0-2.0)$ & $0.82(0-2.0)$ & 3.15 \\
\hline SHRU ${ }^{d}$ & Woody stems $(\mathrm{DBH}<5 \mathrm{~cm}) / \mathrm{ha}$, excluding Smilax spp. / ha & $27,000(9,200-45,600)$ & $38,800(9,800-73,600)$ & $12.23^{*}$ \\
\hline $\mathrm{SSPE}^{\mathrm{b}}$ & Shrub species $/ 50.3 \mathrm{~m}^{2}$ (including tree saplings) & $6(4-9)$ & $6.5(4-10)$ & 0.16 \\
\hline $\mathrm{CLET}^{\mathrm{b}}$ & Clethra alnifolia stems / ha & $14,100(3,600-29,000)$ & $33,800(2,800-70,600)$ & $23.42^{* * *}$ \\
\hline LEUC $^{\mathrm{c}}$ & Leucothoe racemosa stems / ha & $0(0-4,600)$ & $500(0-4,000)$ & 6.15 \\
\hline PERS $^{c}$ & Persea borbonia stems $(\mathrm{DBH}<5 \mathrm{~cm}) / \mathrm{ha}$ & $3,700(0-8,800)$ & $800(0-5,000)$ & $15.37^{* * *}$ \\
\hline SMIL $^{\mathrm{c}}$ & Smilax spp. stems/ha & $3,300(0-41,000)$ & $0(0-6,600)$ & $28.49 * * *$ \\
\hline
\end{tabular}

$\$ P$-values adjusted for number of tests $(n / 24) * P<0.05 ; P<0.01 * * * P<0.001$

Data transformations for principal components and logistic regression analyses: ${ }^{\operatorname{arcsine}}$; ${ }^{\mathrm{b}} \mathrm{qquare}-\operatorname{root}(x)$; ${ }^{\mathrm{c}} \mathrm{square}-\operatorname{root}(x+1) ;{ }^{\mathrm{d}} \log _{10}(x) ;{ }^{\mathrm{e}} \log _{10}(x+1)$. 


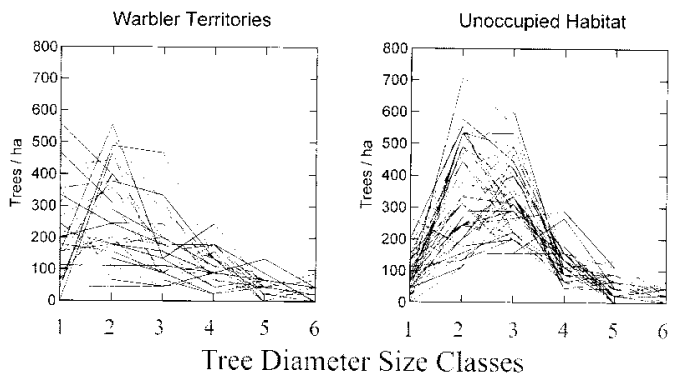

FIG. 2. Parallel coordinate plots of tree diameter classes in Swainson's Warbler territories $(n=30)$ and in unoccupied habitat $(n=44)$ in the Great Dismal Swamp. Size classes (DBH): (1) 5-14.9 cm; (2) 15-24.9 cm; (3) 25-39.9 cm; (4) 40-59.9 cm; (5) 60-79.9 cm; and $(6)>80 \mathrm{~cm}$.

quently, territory data from both years were combined for statistical analyses.

Univariate analyses indicated that 13 of 24 habitat variables exhibited intergroup differences between warbler territories and randomly sampled plots in unoccupied habitat (Table 1 ). The size class distribution of trees (ONESIX) varied substantially among sampling groups $\left(\chi^{2}=172.15, \mathrm{df}=5, P<0.0001\right)$ (Fig. $2)$. Territories contained significantly more trees in the smallest diameter class $(5-14.9 \mathrm{~cm}$ DBH, ONE) but fewer medium-sized trees (25$39.9 \mathrm{~cm} \mathrm{DBH}, \mathrm{THRE})$. The surfeit of mediumsized trees in unoccupied habitat was due primarily to even-aged stands of black gum (NYSS). The density of trees in large diameter classes ( $>40 \mathrm{~cm}$ DBH, FOUR-SIX) and the overall density of trees (TREE) were similar in territories and unoccupied habitat. However, total basal area (BAS) averaged $\sim 16 \%$ less in territories. The density of small woody stems was lower in territories (median $=27,000$ stems per hectare; range, 9,200-45,600) than in unoccupied habitat (median $=38,800$ stems per hectare; range, 9,800-73,600). There were no differences between territories and unoccupied habitat in the number of vines supported by trees.

Habitat floristics. - There was little evidence that Swainson's Warbler selects habitat on the basis of specific floristic cues. Red maple (ACER) was the dominant tree species in warbler territories ( $44.1 \%$ stems; $59.4 \%$ basal area) and in unoccupied habitat (47.1\% stems; $50.2 \%$ basal area). Swamp black gum (NYSS) was nearly as abundant, comprising $27.0 \%$ of stems and $22.2 \%$ of basal area in territories, and $44.1 \%$ of stems and $42.1 \%$ of basal area in unoccupied habitat. No other tree species composed more than 14.4 and $4.2 \%$, respectively, of the stems in territories and unoccupied habitat (Table 2). Territories supported a higher diversity of tree species (TSPE), but there were no differences between occupied and unoccupied habitat in the number of vine (VSPE) or shrub species (SSPE) (Table 1). Three of the four most common shrubs exhibited significant density differences among sampling groups: coastal pepperbush (CLET) was more abundant in unoccupied habitat, whereas fetterbush (LYON) and redbay (PERS) were prominent understory components in warbler territories. Thorny greenbriar (SMIL) tangles were conspicuous components of understory thickets in warbler territories (median $=3,300$ stems per hectare; range, $0-41,000)$, but were far less common in unoccupied habitat (median $=0$ stems per hectare; range, $0-6,600)$.

TABLE 2. Relative abundance and frequency of occurrence of tree species (DBH $>5 \mathrm{~cm})$ in Swainson's Warbler territories and in nearby unoccupied habitat in Great Dismal Swamp.

\begin{tabular}{|c|c|c|c|c|c|c|}
\hline \multirow[b]{2}{*}{ Tree species } & \multicolumn{3}{|c|}{ Territories $(n=30)$} & \multicolumn{3}{|c|}{ Unoccupied habitat $(n=44)$} \\
\hline & $\%$ stems $^{\mathrm{a}}$ & $\%$ basal area ${ }^{a}$ & No. plots & $\%$ stems & $\%$ basal area ${ }^{a}$ & No. plots \\
\hline Acer rubrum & 44.1 & 59.4 & 30 & 47.1 & 50.2 & 44 \\
\hline Nyssa sylvatica & 27.0 & 22.2 & 27 & 44.1 & 42.1 & 44 \\
\hline Persea borbonia & 14.4 & 2.9 & 27 & 4.2 & 0.6 & 28 \\
\hline Ilex ораса & 5.3 & 1.1 & 16 & 2.3 & 0.4 & 20 \\
\hline Liquidambar styraciflua & 4.4 & 5.0 & 10 & 0.7 & 1.8 & 10 \\
\hline Taxodium distichum & 2.1 & 6.0 & 10 & 0.2 & 0.5 & 4 \\
\hline Liriodendron tulipifera & 1.2 & 2.5 & 8 & 0.5 & 0.9 & 8 \\
\hline Other species & $1.6^{\mathrm{b}}$ & 1.0 & NA & $0.6^{c}$ & 3.5 & NA \\
\hline
\end{tabular}

a Percentages do not add to 1.00 due to rounding error.

b Pinus taeda, Quercus nigra, Q. laurifolia, Asimina triloba, Pyrus spp., Vaccinium spp.

c Pinus taeda, Fraxinus spp. 


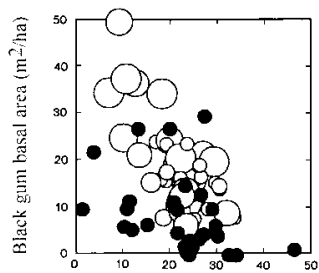

Red maple basal area ( $\mathrm{m}^{2} / \mathrm{ha}$ )
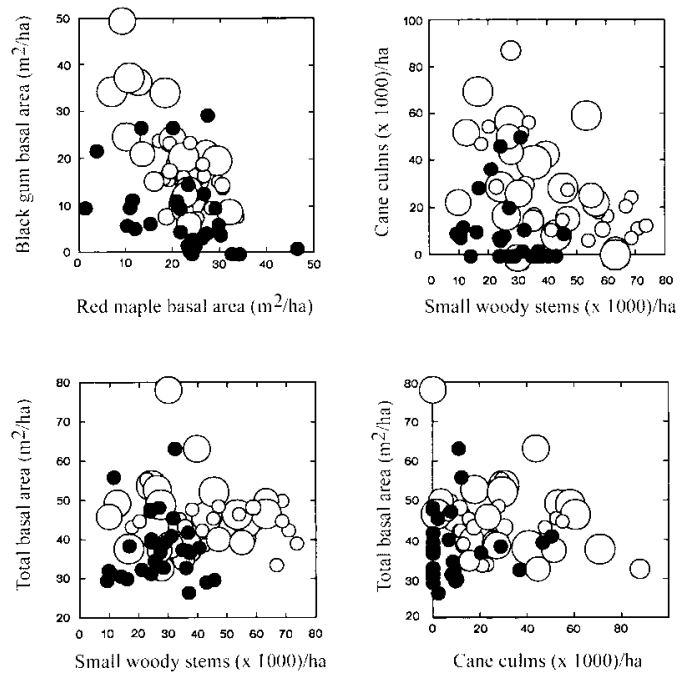

Small woody stems $(x 1000) / h a$

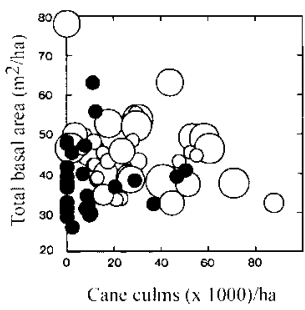

FIG. 3. Scattergrams of selected habitat variables in Swainson's Warbler territories (filled circles $=30$ ) and in unoccupied habitat (open circles $=44$ ) in the Great Dismal Swamp. Circle diameters are proportional to the percentage coverage of pooled water in sampling plots.

The density of giant cane was lower on territories (median $=0$ culms per hectare; range, $0-50,400 /$ ha) than in unoccupied habitat (median $=23,300$ culms per hectare; range, 0 $88,000)$. Moreover, cane was only recorded on $57 \%$ of the vegetation sampling plots (17 of 30) in territories. Patchiness of cane (CVCA) was similar in territories and in unoccupied habitat.

Pooled water.-Hydrology appears to be the driving force influencing vegetation and the distribution of Swainson's Warbler in Great Dismal Swamp (Fig. 3, Table 3). Standing or pooled water (WAT) was logged on $61 \%(43 \%$ of 880 reference points) of the plots in unoccupied habitat. By comparison, water was unrecorded on vegetation plots $(0 \%$ of 600 reference points) in warbler territories, although scattered pools or water-filled ditches occurred within the boundaries of every territory. Pooled water was positively correlated with total basal area (BAS), basal areas of red maple (ACER) and swamp black gum (NYSS), the number of medium-sized trees (THRE), and the densities of cane (CANE) and swamp sweetbells (LEUC), but negatively correlated with the density of small redbay stems (PERS) (Table 3). Several significant floristic correlations appear to be directly attributable to con-
TABLE 3. Correlation between pooled water (WAT) and habitat variables. Significant Spearman rank correlation coefficients $(P<0.05 / 23=0.002$, onetailed) are given in boldface.

\begin{tabular}{lc}
\hline \hline Habitat & Pooled water \\
variable & $\mathbf{0 . 3 5}$ \\
\hline BAS & $\mathbf{0 . 3 6}$ \\
ACER & $\mathbf{0 . 4 7}$ \\
NYSS & -0.12 \\
BOTH & -0.11 \\
ONE & 0.25 \\
TWO & $\mathbf{0 . 3 7}$ \\
THRE & 0.22 \\
FOUR & -0.12 \\
FIVE & 0.03 \\
SIX & 0.29 \\
TREE & -0.22 \\
TSPE & -0.04 \\
VINE & -0.03 \\
VSPE & $\mathbf{0 . 4 4}$ \\
CANE & 0.23 \\
CVCA & 0.05 \\
SHRU & 0.08 \\
SSPE & 0.13 \\
CLET & $\mathbf{0 . 3 7}$ \\
LEUC & -0.16 \\
LYON & $-\mathbf{0 . 3 6}$ \\
PERS & -0.31 \\
SMIL &
\end{tabular}

trasting hydrological adaptations-for example, ACER versus NYSS $\left(r_{\mathrm{s}}=-0.43\right.$, Fig. 3), CLET versus LEUC ( $\left.r_{\mathrm{s}}=-0.46\right)$, CLET versus PERS $\left(r_{\mathrm{s}}=-0.38\right)$, CLET vs. SMIL $\left(r_{\mathrm{s}}=-0.59\right)$.

Multivariate perspective.-From the logistic regression ( $\log$ likelihood, $\chi^{2}=73.07, \mathrm{df}=5, P<$ $0.00001)$, the estimated probability $(P)$ of occurrence of Swainson's Warbler was:

$$
\begin{aligned}
\ln (P /[1-P])= & -1.13-0.01(\mathrm{NYSS}) \\
& -0.61(\mathrm{THRE}) \\
& +0.50 \text { (TREE) } \\
& -0.55 \text { (CANE) } \\
& +0.05 \text { (SMIL) }
\end{aligned}
$$

This model correctly classified the presence or absence of Swainson's Warbler on $90.4 \%$ of the 74 plots (Table 4). Habitat variables strongly associated with the distribution of Swainson's Warbler include the basal area of swamp black gum (NYSS), the number of medium-sized trees (THRE), the total number of trees (TREE), and the densities of cane (CANE) and greenbriar (SMIL). However, the unwieldy number of variables retained in the model does little to 
TABLE 4. Multiple logistic regression models with two or three habitat variables that correctly classify $>80 \%$ of vegetation plots. The presence or absence of Swainson's Warbler was the dependent variable.

\begin{tabular}{|c|c|c|c|}
\hline Regression model & $\begin{array}{c}\text { Log } \\
\text { likelihood }\end{array}$ & $\begin{array}{l}\text { \% correctly } \\
\text { classified }\end{array}$ & $P$ \\
\hline 1. Warbler $=6.28-0.01(\mathrm{NYSS})-0.28(\mathrm{THRE})+0.04(\mathrm{SMIL})$ & 63.90 & 86.6 & $<0.00001$ \\
\hline 2. Warbler $=4.17-0.01(\mathrm{NYSS})-0.60(\mathrm{CANE})+0.05(\mathrm{SMIL})$ & 62.30 & 85.4 & $<0.00001$ \\
\hline 3. Warbler $=-1.02-0.02($ NYSS $)+0.14($ TREE $)+0.06($ SMIL $)$ & 60.67 & 84.7 & $<0.00001$ \\
\hline 4. Warbler $=2.61-0.01($ NYSS $)+0.06($ SMIL $)$ & 59.46 & 84.4 & $<0.00001$ \\
\hline 5. Warbler $=2.92-0.01($ NYSS $)-0.71($ THRE $)+0.36($ TREE $)$ & 58.64 & 83.6 & $<0.00001$ \\
\hline 6. Warbler $=6.75-0.40(\mathrm{THRE})-0.65(\mathrm{CANE})+0.04(\mathrm{SMIL})$ & 58.78 & 83.3 & $<0.00001$ \\
\hline 7. Warbler $=10.42-0.01(\mathrm{NYSS})-0.71(\mathrm{THRE})-0.52(\mathrm{CANE})$ & 54.53 & 82.1 & $<0.00001$ \\
\hline 8. Warbler $=8.96-0.01($ NYSS $)-0.44($ THRE $)$ & 51.70 & 81.2 & $<0.00001$ \\
\hline 9. Warbler $=0.57-0.61($ THRE $)+0.25($ TREE $)+0.03($ SMIL $)$ & 54.33 & 81.0 & $<0.00001$ \\
\hline
\end{tabular}

facilitate the rapid assessment of habitat suitability. How well do less complex models perform? I conducted simple multiple logistic regression analyses on all possible subsets of the variables drawn from the five retained by the initial stepwise regression. Nine simpler models provided reasonably good $(>80 \%)$ classification success (Table 4). In particular, pairwise combinations of NYSS (basal area of swamp black gum), THRE (number of medium-sized trees), and SMIL (number of greenbriar stems) correctly classified $80 \%$ or more of the habitat plots. NYSS $\left(r_{S}=0.47\right)$ and THRE $\left(r_{S}=0.37\right)$ were significantly correlated with the presence of standing water (Table 3 ), and with one another $\left(r_{S}=0.52\right)$. Quantification of two key variables, NYSS and SMIL (84\% correctly classified), may provide a rapid and reasonably reliable assay of habitat suitability in the study area.

\section{DisCUSSION}

The envirogram summarizes the environmental factors that directly (centrum) or indirectly (web) influence or control the distribution and abundance of Swainson's Warbler (Fig. 4). Environmental factors are partitioned into four compartments or submodels according to their effects (negative/positive) on the warbler and the reciprocal effects (negative/positive/ neutral) of the warbler on the factor. Resources are defined as factors that have a positive influence on the warbler but that are unchanged or decreased by the actions of the warbler (e.g. arthropods). Hazards negatively influence the warbler but receive no reciprocal advantage or benefit from the interaction (e.g. flooding). In contrast, predators negatively affect the war- bler and acquire or receive some benefit from the association. The fourth compartment contains factors or components related to reproduction. Because many aspects of the warbler's breeding biology are poorly known, the resulting flow diagram must be regarded as a hypothetical working model. Nevertheless, by focusing attention on the interrelationship between habitat elements and environmental influences that are believed crucial for the maintenance of viable populations, the envirogram serves as a heuristic model for habitat managers and as a guide for future research. The supplementary narrative that follows, as distinguished from logic equations (e.g. Niven and Stewart 1987, Niven and Abel 1991) or envirogram itself, summarizes the best documented components of the web and centrum in nontechnical language.

In the resource compartment of the envirogram, the availability of arthropods is linked to the characteristics of soil and leaf litter and to a cascade of indirect effects. Swainson's Warbler is a terrestrial dead-leaf specialist with a limited repertoire of foraging behaviors directed toward litter arthropods (Meanley 1970, Graves 1998). The quality and quantity of leaf litter depend directly on the taxonomic diversity and basal area of tree species, which in turn depends on hydrology, topography, and soil characteristics. Breeding territories are restricted to moist soils throughout the species' breeding range but periodic flooding can have a profound influence on the year-to-year occupancy of otherwise optimal sites (Meanley 1966, 1971; Graves 1998).

A significant fraction of the remaining Swainson's Warbler habitat, particularly in the lower Mississippi Valley (see Twedt and 


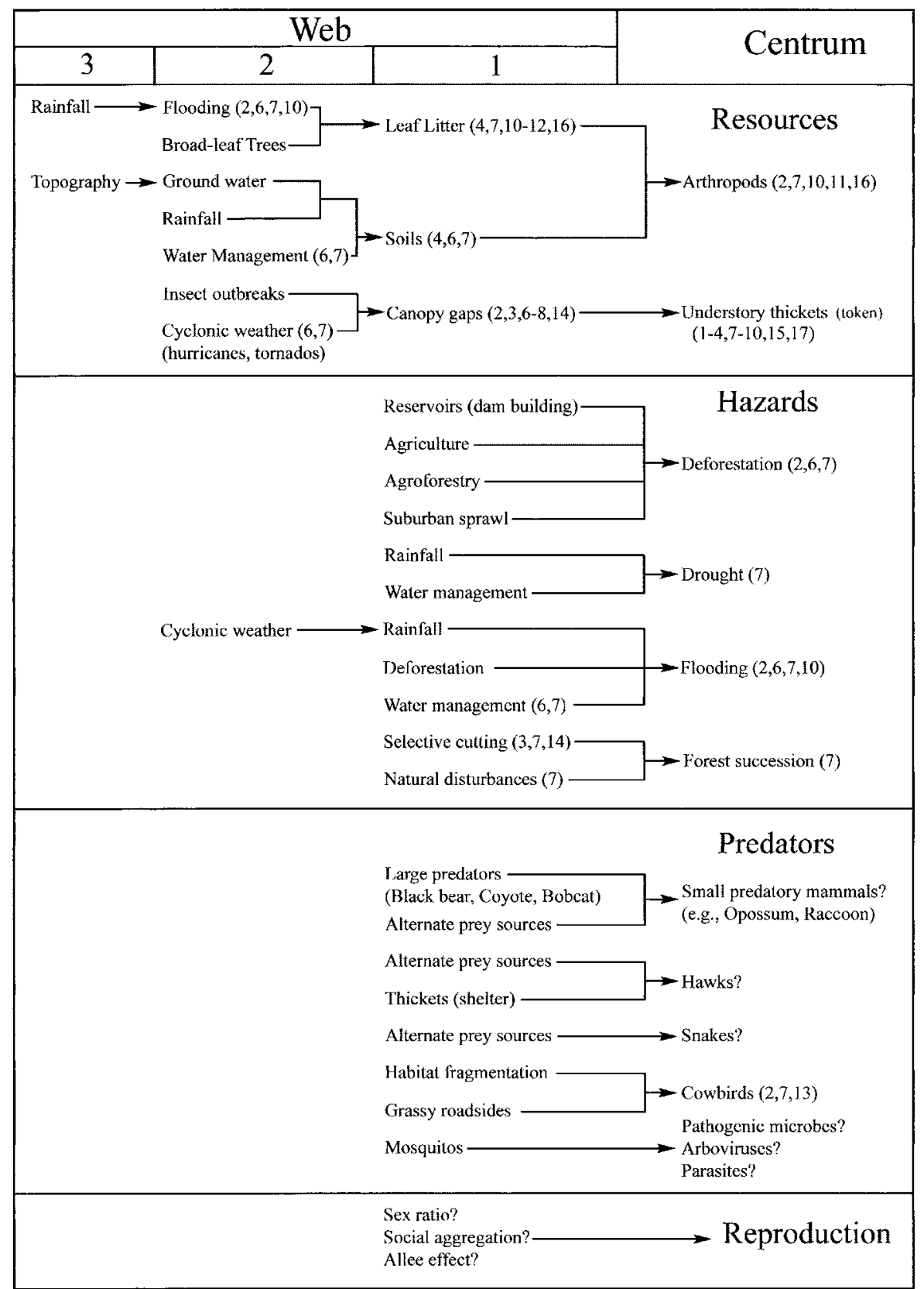

FIG. 4. Envirogram for Swainson's Warbler (Limnothlypis swainsonii). Elements in the submodels (resources, hazards, predators, reproduction) refer specifically to factors relevant to the breeding biology of Swainson's Warbler in Great Dismal Swamp, but also apply generally to breeding populations on the Atlantic and Gulf coastal plains and in the lower Mississippi Valley. Deforestation does not currently threaten populations in Great Dismal Swamp National Wildlife Refuge. "Token" denotes a resource prerequisite for the establishment of territories and for reproduction. Question marks designate hypothesized but unsubstantiated factors. Footnoted references: (1) Brewster 1885a; (2) Brown and Dickson 1994; (3) Eddleman et al. 1980; (4) Graves 1998; (5) Graves et al. 1996; (6) Graves, this paper; (7) G. Graves unpubl. data; (8) Hamel 1981; (9) Meanley 1945; (10) Meanley 1966; (11) Meanley 1970; (12) Meanley 1971; (13) Meanley 1982; (14) Pashley and Barrow 1993; (15) Sims and DeGarmo 1948; (16) Strong 2000; (17) Wayne 1886. 
Loesch 1999), is sandwiched between flood mitigation levees and river channels, where the duration and severity of annual flooding now routinely exceeds annual baselines documented in pre-1920 records (G. Graves unpubl. data). On the short term, flooded territories are vacated. Observations suggest that abandonment is stimulated by the inundation of leaf litter, a critical foraging resource on the breeding and wintering grounds, although nesting sites (0.3-3.1 m above ground) are also affected by severe flooding. Populations displaced by flooding disperse to higher terraces within floodplains or to the margins of swamps, but there is no evidence that displaced populations successfully reproduce in marginal habitats (G. Graves unpubl. data). Much of the observed variance in territory size in Great Dismal Swamp (Meanley 1966, 1969, 1971) and other locations may be explained by annual variation in the water table.

Repeated censuses in several locations indicate that catastrophic floods affect habitat occupancy for several years by scouring and washing away accumulated leaf litter. Many large tracts ( $>500 \mathrm{ha}$ ) of bottomland forest adjacent to river channels and subject to annual flooding (e.g. Alabama River, Pascagoula River) support vanishingly small populations of Swainson's Warblers (G. Graves unpubl. data). Hydroperiod thus emerges as the principal management concern for this species in annually flooded habitats in the core of its geographic range.

Foraging and singing stations of territorial males in Great Dismal Swamp were significantly drier and more floristically diverse than unoccupied sites distributed along a continuous and subtle hydrological gradient. There was insufficient evidence to indicate that floristic cues, to the extent those can be disassociated from physiognomic factors, were used to select territories. Instead, this species seems to evaluate potential territories on the basis of multiscale physiognomic, hydrological, and edaphic characteristics. Territories in Great Dismal Swamp were characterized by extensive understory thickets (median $=36,220$ small woody stems and cane culms per hectare; range 14,000-81,400/ha), frequent greenbriar tangles, deep shade at ground level, and an abundance of leaf litter overlying moist organic soils. Stem densities reported here were rough- ly comparable to those reported for geographically peripheral sites in Missouri (Thomas et al. 1996) and Illinois (Eddleman et al. 1980), and for populations within the core breeding range in Georgia (Meanley 1966), South Carolina (Hamel 1981), Louisiana (G. Graves unpubl. data), Arkansas (G. Graves unpubl. data), Mississippi (G. Graves unpubl. data), and Florida (G. Graves unpubl. data). Habitat optimality, however, does not appear to be linearly correlated with the abundance of small woody stems (Fig. 3). Rather, a range of understory stem densities provides the requisite patches of dense cover associated with nest sites (Brewster 1885b, Wayne 1886, Meanley 1945, 1966, 1970, 1971; Graves 1992, and unpubl. data; Brown and Dickson 1994, Thomas et al. 1996), as well as the sparsely vegetated but heavily shaded glades in which the warblers preferentially forage (Graves 1998). Data from Great Dismal Swamp strengthens the conclusion that giant cane, although often a correlate of habitat occupancy, is not an essential component of optimal habitat. Additionally, canopy height appears to exert little influence in habitat selection beyond the extent to which understory thickets are associated with disturbance gaps in taller closed-canopy forests. Data from numerous sites on the Atlantic and Gulf coastal plains, from the lower Mississippi Valley, and from Great Dismal Swamp indicate a preference for early successional forest in the current landscape or disturbance gaps in primeval forest (e.g. Delta National Forest, Sharkey County, Mississippi; G. Graves unpubl. data). Accordingly, frequent gap simulations should be incorporated in forest restoration efforts aimed at this species (Eddleman et al. 1980, Pashley and Barrow 1993).

Implications for hydrological management.Current management strategies for Swainson's Warbler call for regeneration and maintenance of canebrakes (Eddleman et al. 1980, Thomas et al. 1994), the creation of small canopy gaps by cutting individual trees (Eddleman et al. 1980, Pashley and Barrow 1993), and the generation of larger gaps (up to 4 acres) through clearcutting (Eddleman et al. 1980). On the other hand, hydrology has not been not discussed as a management concern, even though the devastating effects of flooding on breeding populations have been known since Meanley's (1966, 1971) pioneering work along the Ocmulgee 
River. Although a full exploration of hydrological influences on Swainson's Warbler populations is beyond the scope of this paper, a few key points are germane to the present discussion.

Natural hydrological cycles in Great Dismal Swamp were significantly altered by the construction of ditches and canals long before the first biological and geological surveys were made (e.g. Chickering 1873, Kearney 1901). With the exception of periodic assessments of surface levels of Lake Drummond and Dismal Swamp Canal, there are no long-term data useful for establishing hydroperiod baselines for most reference sites in the GDSNWR. Although the refuge is currently partitioned into six water management units, the extensive network of ditches $(240 \mathrm{~km})$ and spoil banks functionally divides the swamp into a patchwork of $40+$ hydrological compartments. Current water management capacities are rudimentary, limited to the manipulation of fixed weirs, control structures, and locks on ditches. Hydrological restoration is an untenable goal without permanently damming ditches at ground level combined with the widescale construction of culverts to breach spoilbanks, permitting the natural flow of water.

Hydrological policy in the GDSNWR was administered with limited personnel on a largely ad hoc basis from the inception of the refuge in 1974 through 1996, favoring the retention of surface water near peak levels during the growing season in order to provide Wood Duck (Aix sponsa) breeding habitat and to promote the growth of bald cypress and water tupelo (L. Culp pers. comm.). An unintended consequence of that practice was the flooding of large tracts of optimal habitat for the ground-foraging Swainson's Warbler. High water levels during the growing season also thwarted efforts to regenerate stands of Atlantic white cedar, which requires exposed soil for germination. Accordingly, concerted efforts have been made since 1996 to permit surface water levels to recede naturally to subsurface levels during the growing season in some hydrological compartments. In any event, the water table of natural areas managed primarily for Swainson's Warbler should be maintained at subsurface levels from March through September.

\section{ACKNOWLEDGMENTS}

This paper is dedicated to Brooke Meanley. I owe special thanks to Kamal Mohamed for collecting vegetation data under physical conditions that few people would voluntarily endure. I thank the staff of Great Dismal Swamp National Wildlife Refuge (Lloyd Culp, David Brownlee, Ralph Keel, Bryan Poovey), Lytton Musselman (Old Dominion University), and Don Schwab (Virginia Department of Game and Inland Fisheries) for field support and assistance. The manuscript benefited from the insightful reviews of Wylie Barrow, Jeff Brawn, Raymond Brown, Lloyd Culp, William Eddleman, Todd Engstrom, Paul Hamel, Frances James, Gerald Niemi, Tom Sherry, and Kevin Winker. Brian Schmidt helped with the figures. Banding permits were issued by the U.S. Fish and Wildlife Service and the Virginia Department of Game and Inland Fisheries. The project was funded by the Smithsonian Research Opportunities Fund and the U.S. Fish and Wildlife Service (14-48-0005-92-9013 and 14-48-0009-946).

\section{Literature Cited}

Andrewartha, H. G., AND L. C. BirCH. 1984. The Ecological Web: More on the Distribution and Abundance of Animals. University of Chicago Press, Chicago.

BECKHAM, C. W. 1887. Additions to the avi-fauna of Bayou Sara, Louisiana. Auk 4:299-306.

BENKMAN, C. 1999. The selection mosaic and diversifying coevolution between crossbills and lodgepole pine. American Naturalist 153(Supplement):75-91.

BREWSTER, W. 1885a. Swainson's Warbler. Auk 2:6580.

BREWSTER, W. 1885b. The nest and eggs of Swainson's Warbler (Helinaia swainsoni). Forest and Stream 24:468.

BROOKS, M., AND W. C. LEGG. 1942. Swainson's Warbler in Nicholas County, West Virginia. Auk 59: 76-86.

BROWN, R. E., AND J. G. DiCKSON. 1994. Swainson's Warbler (Limnothlypis swainsonii). In The Birds of North America, no. 126 (A. Poole and F. Gill, Eds.). Academy of Natural Sciences, Philadelphia, and American Ornithologists' Union, Washington, D.C.

BYRD, W. 1967. Histories of the dividing line betwixt Virginia and North Carolina. (Reprint.) Dover Publications, New York.

Carter, V., P. T. GAMmON, AND M. K. Garrett. 1994. Ecotone dynamics and boundary determination in the Great Dismal Swamp. Ecological Applications 4:189-203.

CARter, V., M. K. Garrett, AND P. T. GAMmon. 1988. Wetland boundary determination in the Great 
Dismal Swamp using weighted averages. Water Resources Bulletin 24:297-306.

Chickering, J. W. 1873. The flora of the Dismal Swamp. American Naturalist 7:521-524.

CODY, M. L., ED. 1985. Habitat Selection in Birds. Academic Press, Orlando, Florida.

Collins, S. L. 1983. Geographic variation in habitat structure of the Black-throated Green Warbler (Dendroica virens). Auk 100:382-389.

Dow, D. D. 1968. Home range and habitat of the cardinal in peripheral and central populations. Canadian Journal of Zoology 47:103-114.

Eddleman, W. R., K. E. Evans, and W. H. Elder. 1980. Habitat characteristics and management of Swainson's Warbler in southern Illinois. Wildlife Society Bulletin 8:228-233.

FrAnZREB, K. E. 1978. Tree species used by birds in logged and unlogged mixed-coniferous forests. Wilson Bulletin 90:221-238.

Fretwell, S. D., AND H. L. LuCAS, JR. 1970. On territorial behavior and other factors influencing habitat distribution in birds. I. Theoretical development. Acta Biotheoretica 19:16-36.

GRAVES, G. R. 1992. A case of aggregated nest placement and probable polygyny in the Swainson's Warbler. Wilson Bulletin 104:370-373.

Graves, G. R. 1996. Censusing wintering populations of Swainson's Warblers: Surveys in the Blue Mountains of Jamaica. Wilson Bulletin 108:94103.

GRAVES, G. R. 1998. Stereotyped foraging behavior of the Swainson's Warbler. Journal of Field Ornithology 69:121-127.

Graves, G. R., M. B. Simpson, Jr., And L. D. StePHENS. 1996. Joseph LeConte and the discovery of the nest of Swainson's Warbler (Limnothlypis swainsonii): A reconsideration. Archives of Natural History 23:287-290.

GREENBERG, R. 1984. The role of neophobia in the foraging site selection of a tropical migrant bird: An experimental study. Proceedings of the National Academy of Sciences USA 81:3778-3780.

GRINNELL, J. 1917. Field tests and theories concerning distributional control. American Naturalist 51:115-128.

HAMEL, P. B. 1981. A hierarchical approach to avian community structure. Ph.D. dissertation, Clemson University, Clemson, South Carolina.

Holmes, R. T., AND S. K. Robinson. 1981. Tree species preferences of foraging insectivorous birds in a northern hardwood forest. Oecologia 48:3135.

Hosmer, D. W., JR., AND S. Lemeshow. 1989. Applied Logistic Regression. John Wiley and Sons, New York.

Howell, A. H. 1924. Birds of Alabama. Bureau of Biological Survey, U.S. Department of Agriculture and Department of Game and Fisheries, Brown Printing Company, Montgomery, Alabama.
Howell, A. H. 1932. Florida Bird Life. Department of Game and Fresh Water Fish, Coward-McCann Inc., New York.

Hunter, W. C., D. N. Pashley, and R. E. F. Escano. 1993. Neotropical migratory landbird species and their habitats of special concern with the southeast region. Pages 159-171 in Status and Management of Neotropical Migratory Birds (D. M. Finch and P. W. Stangel, Eds.). U.S. Forest Service General Technical Report RM-229, Fort Collins, Colorado.

James, F. C., C. A. Hess, And D. Kufrin. 1997. Species-centered environmental analysis: Indirect effects of fire history on Red-cockaded Woodpecker. Ecological Applications 7:118-129.

JAmEs, F. C., R. F. JOHNSTON, N. G. WAMER, G. J. NieMI, AND W. J. BoECKLEN. 1984. The Grinnellian niche of the Wood Thrush. American Naturalist 124:17-30.

JAmes, F. C., AND H. H. Shugart, JR. 1970. A quantitative method of habitat description. Audubon Field Notes 24:727-736.

KEARNEY, T. H. 1901. Report on a botanical survey of the Dismal Swamp region. Contributions from the U.S. National Herbarium 5:321-550.

KLuijver, H. N. 1951. The population ecology of the Great Tit, Parus m. major L. Ardea 39:1-135.

LACK, D. 1933. Habitat selection in birds. Journal of Animal Ecology 2:239-262.

LeVy, G. F. 1991. The vegetation of the Great Dismal Swamp: A review and an overview. Virginia Journal of Science 42:411-417.

LeVy, G. F., AND S. W. WALKer. 1979. Forest dynamics in the Dismal Swamp of Virginia. Pages 101-126 in The Great Dismal Swamp (P. W. Kirk, Jr., Ed.). University of Virginia Press, Charlottesville.

LICHTLER, W. F., AND P. N. WALKER. 1979. Hydrology of the Dismal Swamp, Virginia-North Carolina. Pages 140-187 in The Great Dismal Swamp (P. W. Kirk, Jr., Ed.). University of Virginia Press, Charlottesville.

MacArthur, R. H. 1958. Population ecology of some warblers of northeastern coniferous forests. Ecology 39:599-619.

MeAnleY, B. 1945. Notes on Swainson's Warbler in central Georgia. Auk 62:395-401.

MEANLEY, B. 1966. Some observations on habitats of the Swainson's Warbler. Living Bird 5:151-165.

MeAnley, B. 1969. Pre-nesting and nesting behavior of the Swainson's Warbler. Wilson Bulletin 81: 246-257.

MeAnley, B. 1970. Method of searching for food by the Swainson's Warbler. Wilson Bulletin 82:228.

MEANLEY, B. 1971. Natural history of the Swainson's Warbler. North America Fauna, no. 69.

MEANLeY, B. 1982. Swainson's Warbler and the cowbird in the Dismal Swamp. Raven 53:47-49. 
Morse, D. H. 1989. American Warblers: An Ecological and Behavioral Perspective. Harvard University Press, Cambridge, Massachusetts.

MorTON, E. S. 1990. Habitat segregation by sex in the Hooded Warbler: Experiments on proximate causation and discussion of its evolution. American Naturalist 135:319-333.

MORTON, E. S., M. VAN DER VOORT, AND R. GREENBERG. 1993. How a warbler chooses its habitat: Field support for laboratory experiments. Animal Behaviour 46:47-53.

Musselman, L. J., D. L. Nickrent, AND G. F. LeVy. 1977. A contribution towards a vascular flora of the Great Dismal Swamp. Rhodora 79:240-268.

Niven, B. S., AND D. E. Abel. 1991. Logical synthesis of environment of King Penguin, Aptenodytes patagonicus. Ecological Modelling 56:291-311.

Niven, B. S., AND M. G. STEWART. 1987. Logical synthesis of an animal's environment: Sponges to non-human primates. II. The freshwater sponge, Spongilla lacustris. Australian Journal of Zoology 35:607-624.

NOLAN, V., JR. 1978. The ecology and behavior of the Prairie Warbler Dendroica discolor. Ornithological Monographs, no. 26.

OAKS, R. Q., JR., AND N. K. COCH. 1973. Post-Miocene Stratigraphy and Morphology, Southeastern Virginia. Virginia Division of Mineral Resources Bulletin 82.

OAKS, R. Q., JR., AND D. R. WhitehEAD. 1979. Geologic setting and origin of the Dismal Swamp, southeastern Virginia and northeastern North Carolina. Pages 1-24 in The Great Dismal Swamp (P. W. Kirk, Jr., Ed.). University of Virginia Press, Charlottesville.

Orians, G. H., AND J. F. WitTenberger. 1991. Spatial and temporal scales in habitat selection. American Naturalist 137(Supplement):29-49.

PARRISH, J. D. 1995. Effects of needle architecture on warbler habitat selection in a coastal spruce forest. Ecology 76:1813-1820.

PARTRIDGE, L. 1976. Field and laboratory observations on the foraging and feeding techniques of Blue Tits (Parus caeruleus) and Coal Tits (Parus ater) in relation to their habitats. Animal Behaviour 24:534-544.

PAshley, D. N., AND W. C. BARrow. 1993. Effects of land use practices on Neotropical migratory birds in bottomland hardwood forests. Pages 315-320 in Status and Management of Neotropical Migratory Birds (D. M. Finch and P. W. Stangel, Eds.). U.S. Forest Service General Technical Report RM-229, Fort Collins, Colorado.

Pearson, T. G., C. S. Brimley, AND H. H. Brimley. 1919. Birds of North Carolina. Edwards and Broughton Printing Company, Raleigh, North Carolina.
Price, J., S. Droege, And A. Price. 1995. The Summer Atlas of North American Birds. Academic Press, London.

Rappole, J. H. 1995. The Ecology of Migrant Birds. Smithsonian Institution Press, Washington, D.C.

Reber, E. J., M. A. Bailey, P. J. Swecker, J. S. QueSENBERRY, AND D. BRADSHAW. 1981. Soil Survey of the City of Suffolk, Virginia. Soil Conservation Service, U.S. Department of Agriculture, Suffolk, Virginia.

Robbins, M. B., AND D. A. EAsterla. 1992. Birds of Missouri: Their Distribution and Abundance. University of Missouri Press, Columbia.

Robinson, S. K., AND R. T. Holmes. 1984. Effects of plant species and foliage structure on the foraging behavior of forest birds. Auk 101:672-684.

RotenberRy, J. T. 1985. The role of habitat in avian community composition: Physiognomy or floristics? Oecologia 67:213-217.

Sims, E., AND W. R. DeGARMO. 1948. A study of Swainson's Warbler in West Virginia. Redstart 16:1-8.

Smith, C. R., D. M. Pence, AND R. J. O'CONNOR. 1993. Status of Neotropical migratory birds in the Northeast: A preliminary assessment. Pages 172-188 in Status and Management of Neotropical Migratory Birds (D. M. Finch and P. W. Stangel, Eds.). U.S. Forest Service General Technical Report RM-229, Fort Collins, Colorado.

SPSS INC. 1998. SYSTAT Version 8. Chicago.

Strong, A. M. 2000. Divergent foraging strategies of two neotropical migrant warblers: Implications for winter habitat use. Auk 117:381-392.

Terborgh, J. 1989. Where Have all the Birds Gone? Princeton University Press, Princeton, New Jersey.

Thomas, B. G., E. P. Wiggers, and R. L. Clawson. 1996. Habitat selection and breeding status of Swainson's Warbler in southern Missouri. Journal of Wildlife Management 60:611-616.

ThOMPSON, F. R. III, S. J. LEWIS, J. GREEN, AND D. EWERT. 1993. Status of neotropical migrant landbirds in the Midwest: Identifying species of management concern. Pages 145-158 in Status and Management of Neotropical Migratory Birds (D. M. Finch and P. W. Stangel, Eds.). U.S. Forest Service General Technical Report RM229, Fort Collins, Colorado.

TweDt, D. J., AND C. R. LoESCH. 1999. Forest area and distribution in the Mississippi alluvial valley: Implications for breeding bird conservation. Journal of Biogeography 26:1215-1224.

U. S. Weather Bureau. 1965. Climatic survey of the U.S., 1951-1960, Virginia. Washington, D.C.

VAn Horne, B. 1983. Density as a misleading indicator of habitat quality. Journal of Wildlife Management 47:893-901.

Van Horne, B., And J. A. Wiens. 1991. Forest bird habitat suitability models and the development 
of general habitat models. United States Fish and Wildlife Research 8:1-31.

WAYNE, A. T. 1886. Nesting of Swainson's Warbler in South Carolina. Ornithologist and Oologist 11: 187-188.

WhiteHEAD, D. R. 1972. Developmental and environmental history of the Dismal Swamp. Ecological Monographs 42:301-315.

WhiteheAD, D. R., AND R. Q. OAKs. 1979. Developmental history of the Dismal Swamp. Pages 25-
43 in The Great Dismal Swamp (P. W. Kirk, Jr., Ed.). University of Virginia Press, Charlottesville. WIDMANN, O. 1895. Swainson's Warbler an inhabitant of the swampy woods of southeastern Missouri. Auk 12:112-117.

WiEns, J. A. 1989. The Ecology of Bird Communities. Cambridge University Press, Cambridge, Massachusetts.

Associate Editor: J. Brawn 